\title{
Tamanu oil and skin active properties: from traditional to modern cosmetic uses
}

\author{
Phila Raharivelomanana ${ }^{1, *}$, Jean-Luc Ansel ${ }^{1}$, Elise Lupo ${ }^{2}$, Lily Mijouin $^{2,3}$, Samuel Guillot ${ }^{4}$, \\ Jean-François Butaud ${ }^{5}$, Raimana $\mathrm{Ho}^{1}$, Gaël Lecellier ${ }^{6}$ and Chantal Pichon ${ }^{2}$ \\ ${ }^{1}$ Université de la Polynésie Française, UMR 241, BP 6570 Faa'a, 98702 Faa'a, Tahiti, Polynésie Française \\ 2 Centre de Biophysique Moléculaire, CNRS, rue Charles Sadron, 45071 Orléans cedex 2, France \\ ${ }^{3}$ Remedials Laboratoire, 91 rue du faubourg Saint-Honoré, 75008 Paris, France \\ ${ }^{4}$ Université d'Orléans, UMR 7374, 1 b rue de la Férollerie, CS 40059, 45071 Orléans cedex, France \\ ${ }^{5}$ Consultant en foresterie et botanique, BP 52832, 98716 Pirae, Tahiti, Polynésie Française \\ ${ }^{6}$ Université de Versailles Saint-Quentin en Yvelines, 55 Avenue de Paris, 78000 Versailles, France
}

Received 20 May 2018 - Accepted 28 August 2018

\begin{abstract}
Calophyllum inophyllum L. (Calophyllaceae), locally called "tamanu" in French Polynesia, is an evergreen pantropical tree growing mostly along the seashores. Its barks, leaves, and fruits are still used in traditional medicine. The oil expressed from the nuts has been also traditionally used. Tamanu oil is topically applied on skins as well as mucous membrane lesions. This oil is especially recommended to heal all kinds of skin ailments. Bioassays and different assessments of Tamanu oil revealed numerous biological activities (antioxidant, anti-inflammatory, antibacterial, wound healing...), so bringing scientific evidence of beneficial effects of this oil on human skin healing. Such biological properties may explain the use of tamanu oil as an active cosmetic ingredient recorded as "Calophyllum inophyllum seed oil" by the INCI (International Nomenclature of Cosmetic Ingredients). Most of the bioactive properties of tamanu oil are attributed to oil composition including the presence of resinous compounds in tamanu oil beside common fatty acids, which constitutes a unique characteristic of this healing oil. Actually, resinous part of tamanu oil is known to contain bioactive secondary metabolites mostly constituted by neoflavonoids including pyranocoumarin derivatives. Herein, chemical constituents and biological properties of tamanu oil are presented with a focus of its traditional use inspiring modern valuations related to cosmetic field.
\end{abstract}

Keywords: tamanu oil / Calophyllum inophyllum / Cosmetopoeia / neoflavonoids / cosmeceutical

Résumé - L'huile de Tamanu et ses propriétés dermatologiques: des usages traditionnels à la cosmétique moderne. Calophyllum inophyllum L (Calophyllacée), appelé localement «tamanu» en Polynésie française, est un arbre pérenne tropical, poussant le plus souvent le long des rivages marins. Ses écorces, feuilles et fruits, dont l'huile extraite de ses noix, sont encore couramment utilisés en médecine traditionnelle. L'huile de tamanu est particulièrement recommandée pour traiter différentes sortes d'affections dermatologiques et soins de la peau, et est employée en application topiques aussi bien sur la peau que sur les lésions membranaires de la muqueuse. Différentes études scientifiques menées sur l'huile de tamanu, avec notamment des tests d'activités biologiques ciblées, ont révélé de nombreuses propriétés biologiques (anti-oxydante, anti-inflammatoire, antibactérienne, cicatrisante...), prouvant ainsi les effets bénéfiques de cette huile sur les soins de la peau humaine. Ces propriétés biologiques avérées confortent l'utilisation de l'huile de tamanu comme un ingrédient actif en cosmétique, enregistrée sous la dénomination «huile de noix de Calophyllum inophyllum» par l'INCI (International Nomenclature of Cosmetic Ingredients). La plupart des propriétés biologiques de l'huile de tamanu est ainsi attribuée au contenu de cette huile, incluant la présence de composés résineux de l'huile à côté des acides gras communs qui constituent une caractéristique unique de cette huile de soin. En effet, la partie résineuse de l'huile de tamanu

*Correspondance: phila.raharivelomanana@upf.pf 
contient des métabolites secondaires bioactifs, principalement constitués de néoflavoïdes incluant des dérivés de pyranocoumarines. Ainsi, les constituants chimiques et les propriétés de l'huile de tamanu seront présentés en se focalisant sur ses usages traditionnels et sa valorisation dans le domaine de la cosmétique.

Mots clés : huile de tamanu / Calophyllum inophyllum / Cosmétopée / néoflavonoïdes / ingrédient cosmétique

\section{Introduction}

"Cosmetopoeia" refers to popular uses of plants for traditional cosmetic and body care that have always existed in many countries and cultures over the world, but this concept is still very poorly documented as written reports. "Cosmetopoeia" concerns the compilation of plants and their traditional uses for bodycare and well-being or beauty regards related to a region by the local population (as its cultural heritage). Calophyllum inophyllum L. (Calophyllaceae) is an evergreen pantropical tree distributed in Africa, Asia and Pacific countries from where its medicinal and cosmetic traditional uses for centuries had been reported (Stevens, 1980; Florence, 2004; Dweck \& Meadows, 2002). Locally called "tamanu" in French Polynesia, this tree is mostly found growing along the seashores or around the "marae", and was considered as a sacred tree in ancient times. The oil expressed from the nuts, called "tamanu oil", has been traditionally used for many purposes and mainly for topical applications on skins as well as mucous membrane lesions. This oil is especially recommended for the cure of all kinds of dermal affections (burns, dermatoses, eczema, acne, psoriasis, chilblains, skin cracks, diabetic sores, hemorrhoids, dry skin, etc.). Due to its calming and relieving pain effects, the oil is used in massages, for rheumatisms and sciatica soothing, and also highly appreciated for wound healing and analgesic properties (Pétard, 1986; Whistler, 1992; Dweck and Meadows, 2002; Khilam, 2004). The efficiency of tamanu oil has been shown not only through traditional medicine uses for centuries but also by its use on hospitalized patients for significant diminution of scars, so considered in vivo like reported studies (Mariette-Chanson, 2006). These longtime traditional uses of "tamanu oil" led to consider that this oil is one major Polynesian cosmetopoeia product which deserved more scientific investigations to rationalize its uses as a cosmetic ingredient (Ansel et al., 2015). Aiming to show "tamanu oil" potential skin effect, we present herein briefly:

- its physical and chemical characteristics;

- its biological activities and properties related to skin treatment for cosmeceutical regards.

\section{Physical and chemical characteristics of tamanu oil}

\subsection{Obtention of tamanu oil and physico-chemical characteristics}

Tamanu oil process: ripe fruits of Calophyllum inophyllum are first sun dried for one to two months to allow the oil biosynthesis and accumulation in the nuts. Dried nuts are deshelled and submitted to a mechanical cold pressure to yield a viscous yellowish to greenish virgin "tamanu oil" (40-60\% by weight) having strong walnut-like specific aroma. This raw oil was filtered before use and packing.

Physico-chemical characteristics of tamanu oil are as follows:

- density: (0.890-0.934);

- refractive index: $\mathrm{n}_{\mathrm{D}}{ }^{25}(1.4746-1.4822)$;

- saponification index: (183-206);

- acidic index (mg KOH/g): (13-46);

- iodide index: (82-98);

- peroxide index: (0-90);

- unsaponified components: $(0.15-0.85)$;

- resinous: $(10 \%-20 \%)$.

\subsection{Fatty acids}

Triglycerides of tamanu oil are characterized by classical fatty acid composition as follows (a mean found for 5 tamanu oils from different origins): palmitic acid $(16.5 \pm 1.59 \%)$, palmitoleic acid $(0.26 \pm 0.11 \%)$, stearic acid $(30.2 \pm 4.36 \%)$, oleic acid (23.6 $\pm 4.77 \%)$, linoleic acid $(25.5 \pm 3.87 \%)$, alphalinoleic acid $(0.26 \pm 0.05 \%)$, arachidonic acid $(0.6 \pm 0.09 \%)$, gadoleic acid $(0.3 \pm 0.1 \%)$, dihomo-gamma-linolenic acid $(<0.1 \%)$, behenic acid $(0.1 \pm 0.15 \%)$, docosadienoic acid $(1.4 \pm 5.08 \%)$. Saturated fatty acids (SFA) are the major constituents $(41-52 \%)$ with a relative high proportion of stearic acid $(25-35 \%)$. Unsaturated fatty acids (18-22\%), monounsaturated acids (MUFA) and polyunsaturated acids (PUFA) are found in good amounts present respectively as oleic acid (20-26\%) and linoleic acid (21-29\%) (Léguillier et al., 2015).

\subsection{Resinous composition: neoflavonoids and pyranocoumarins}

Tamanu oil contained also an ethanol soluble resinous part (ranging 20\% of the oil), which is comprised mainly of secondary metabolites mostly composed by neoflavonoids and pyranocoumarin derivatives (Lederer et al., 1953; Laure, 2005; Bruneton, 2009; Leu et al., 2009). Following their structural features, these compounds are classified as inophyllums (within a phenyl substituent), calanolides (within a propyl substituent), or tamanolides (within a sec-isobutyl substituent) but the major constituent is always the calophyllolide (an inophyllum derivative). The main components of French Polynesian "tamanu oil" resinous part are: calophyllolide, inopyllums (C, D, E, P), calanolides (A, B, D), tamanolides (D, P) (Leu, 2009; Ansel et al., 2016).

\section{Biological activities}

Biological activity related to skin affections and tamanu oil were put in evidence and reported by different authors, and so 
enlightened its benefic effects such as an antioxidant, antibacterial, antifungal, anti-inflammatory and showing wound healing effects.

\subsection{Antioxidant and anti-UV properties}

Antioxidant effect of tamanu oil had been shown by significantly reducing the intracellular ROS production (Said et al., 2007). Significant radical scavenging effects of some neoflavonoid constituents of tamanu oil resin were found from DPPH assay results of some constituents: inophyllum $\mathrm{E}\left(\mathrm{IC}_{50}\right.$ : $4.8 \mu \mathrm{M})$, inocalophyllin $\mathrm{B}\left(\mathrm{IC}_{50}: 5.7 \mu \mathrm{M}\right)$ and inophyllum $\mathrm{C}$ $\left(\mathrm{IC}_{50}: 6.92 \mu \mathrm{M}\right)$ and thus, related to antioxidant potential of these compounds (Leu, 2009). Beyond the antioxidant effect, the study reports that amongst different oils, Calophyllum inophyllum was the only one that also possessed good capacity to absorb UV light within a significant absorption spectrum from 260 to $400 \mathrm{~nm}$. Actually, $85 \%$ of the DNA damage induced by UV-radiations was shown to be inhibited with $1 \%$ of Calophyllum oil without any in vivo ocular irritation. Because UV-radiations can also induce harmful reactive oxygen species production for ocular system, these results led to suggest that Calophyllum inophyllum oil presents both UVabsorption and antioxidant properties that might contribute to its use as a vehicle in ophthalmic preparations, free of cytotoxicity and associated to an important sun protector factor (18-22).

\subsection{Antimicrobial}

Tamanu oil had been reported to have interesting antimicrobial activities including antibacterial, antifungal effects especially for related skin pathogenic strains.

\subsubsection{Antibacterial activity}

Tamanu oil neoflavonoid constituents were found to have antibacterial activity against Staphylococcus aureus strain, namely calophyllolide (MIC: $16 \mu \mathrm{g}$ ), inophyllum C (MIC: $10 \mu \mathrm{g}$ ) and inophyllum $\mathrm{E}$ (MIC: $13 \mu \mathrm{g}$ ), which activities were shown to be stronger than that of the antibiotic standard oxacillin $(30 \mu \mathrm{g})$ (Yimdjo et al., 2004). These results suggested the bactericidal effect of tamanu oil constituents.

Calophyllum inophyllum oil (CIO) was shown to exhibit high antibacterial activity against bacteria involved in skin infections. Very interesting antibacterial activities were shown on aerobic Gram+ bacteria tested strains such as Staphylococcus aureus (as a multi-drug resistant involved in nosocomial and skin infections), Bacillus cereus associated to wound infections in postsurgical patients and cutaneous infections subsequent to trauma, Staphylococcus epidermidis and Staphylococcus haemolyticus responsible for catheter associated infections and Corynebacterium minutissimum implicated in erythrasma. Moreover, all the tested CIO against Gram + bacteria species present MIC value similar or lower than ofloxacin taken as a positive control. From the same experiments, CIO was also shown to exhibit high antibacterial activity (within MIC value similar or lower than ofloxacin) against bacterial strains involved in acne (Propionibacterium species) such as Propionibacterium acnes and Propionibacterium granulosum, thus suggesting the potential of CIO for acne treatment (Léguillier et al., 2015). As there is no chemical structure similarity between ofloxacin and tamanu oil neoflavonoids, the observed high antimicrobial activity of this oil cannot be explained easily by chemical structure features, and its mode of action should be studied beyond structure relationship activity.

\subsubsection{Antifungal activity}

Antifungal activities of tamanu oil ethanol extract (at a concentration of $4 \mu \mathrm{g} / \mathrm{mL}$ ) had been reported, showing stronger inhibiting activity on various fungal strains (Candida albicans, Candida tropicalis, Aspergillus niger, Aspergillus fumigatus, Alternaria tenuissima) than fluconazole $(10 \mu \mathrm{g})$ taken as a positive control (Saravan et al., 2011).

\subsection{Anti-inflammatory}

The calophyllolide molecule in Calophyllum inophyllum oil had been reported to possess an anti-inflammatory activity, comparatively to hydrocortisone $(10 \mathrm{mg})$ taken as positive control on formaldehyde induced arthritis inflammation, showing an effectiveness from its efficient dose (ED) of $140 \mathrm{mg} / \mathrm{kg}$ and its lethal dose (DL) of $2.5 \mathrm{~g} / \mathrm{kg}$ (Bhalla et al., 1980). Calophyllolide, isolated from Calophyllum inophyllum, had been shown to prevent a prolonged inflammatory process by reducing myeloperoxidase (MPO) activity and downregulation of the pro-inflammatory cytokines-IL-1 $\beta$, IL-6, TNF- $\alpha$, but up-regulation of the anti-inflammatory cytokine, IL-10. The underlying molecular mechanism was also related to an increase of M2 macrophage skewing, as shown by upregulation of M2-related gene expression (Nguyen et al., 2017)

\subsection{Wound healing}

Tamanu oil promotes wound healing in keratinocyte cells (HaCaT) and also in fibroblast cells (HMDF). Tamanu oil was emulsified to obtain TOE (tamanu oil emulsion) from which wound healing experiments were realized on both keratinocytes (HaCaT) and fibroblasts (HDF) confluent and then scratched monolayer cells using different concentrations of TOE $(1 / 100,1 / 200$ and $1 / 400)$ or $25 \mu \mathrm{g} / \mathrm{mL}$ Vitamin C. Wound closure was followed by video microscopy (fully motorized microscope) during $24 \mathrm{~h}$ Wound healing assays showed that $1 \%$ TOE accelerated the wound closure of the scratched fibroblast monolayer: the gap was closed after $14 \mathrm{~h}$, faster than in vitamin C-treated cells (Ansel et al., 2016).

Calophyllolide (isolated from Calophyllum inophyllum) was also reported to reduce fibrosis formation and effectively promoted wound closure in mouse model and so showing a plausible role for calophyllolide in accelerating the process of wound healing through anti-inflammatory activity mechanisms (Nguyen et al., 2017).

\subsection{Dermal and epidermal extra-cellular matrix effects}

The skin-active effect of "tamanu oil emulsion" was investigated on human skin cell cultures (keratinocytes and 
dermal fibroblasts) showing: cell proliferation, glycosaminoglycan and collagen production as well as wound healing activity (Ansel et al., 2016).

The skin-active effect of "tamanu oil emulsion" (TOE) was investigated on human skin cell cultures (keratinocytes HaCAT and dermal fibroblasts HDF) showing cell proliferation (for up to $18 \mathrm{~h}$ incubation time) with an increase (relative to the control cells) of $10-40 \%$ for $\mathrm{HaCaT}(0.25-1 \% \mathrm{TOE})$ and of $5-20 \%$ for HDF at all dilutions.

Glycosaminoglycan (GAG) and collagen production, as well as wound healing activities were evaluated by application of $1 \%$ TOE on treated cells (HaCaT and HDF). An increase of collagen production ( 10 to $40 \%$ ) was observed with a similar level for both cell types depending on the duration of incubation.

Transcriptomic analysis on treated cells revealed gene expression modulation including 223 genes involved in metabolic process for main biological pathways implied in the observed cell activities (Conesa et al., 2005; Harrow et al., 2012). On the 201 sequences, whom the cellular component was assigned, $59.7 \%$ are membrane products. A significant assignation for the extracellular relationships is observed with $37.3 \%$ of sequences to cell periphery, $27.36 \%$ to extracellular region and $13.93 \%$ to cell junction. For the biological process of these gene products (192 sequences were assigned), $56.25 \%$ are involved in response to stimulus (response to abiotic, chemical, endogenous stimuli, etc.) such as cell migration and hypoxia, $74.28 \%$ are involved in metabolic process, such as 2-galactosyltransferases and 1fucosyltransferase (FUT9) implied in O-glycan biosynthesis, $11.98 \%$ are involved in cell adhesion and $13.20 \%$ in cell proliferation.

The biological processes of re-epithelialization following a wound are well-known (Martin, 1997; Sivamani et al., 2007; Krafts, 2010). They imply epidermal cell migration and proliferation, restoration of barrier function by the consolidation of the extra-cellular matrix, and remodeling with collagen fiber rearrangement and cell junctions development. It is important to notice that the differently expressed and annotated genes are mostly implied in these different processes (Ansel et al., 2016).

Bioactive neoflavonoid constituents in TOE may contribute to these biological activities. Altogether consistent data related to targeted histological and cellular functions brought new highlights on mechanisms involved in these biological processes induced by tamanu oil effect on human skin cells (Ansel et al., 2016).

\section{Conclusions}

Biological activity studies confirmed skin-active effects of tamanu oil treatment and an antimicrobial (antibacterial and antifungal) protection, anti-inflammatory, wound healing, promotion of extra-matrix cellular (production of GAG and collagen). The biological properties may explain the use of tamanu oil as an active cosmetic ingredient recorded as "Calophyllum inophyllum seed oil" by the INCI (International Nomenclature of Cosmetic Ingredients). Due to its properties and benefits, tamanu oil is included in different cosmetic formulation as an active ingredient such as for skin regeneration, after sun protection, soothing and irritation calming, wrinkle and stretch mark prevention (Hostettmann, 2011). Indeed traditional uses of tamanu oil such as "monoi" ingredient was good source of inspiration for its cosmetic modern uses and new ways of valuation.

As shown for tamanu oil, an ethnocosmetic product, "cosmetopoeia concept" cares about traditional cosmetic and dermocosmetic uses of natural products and should be investigated by a multidisciplinary approach integrating complementary fields such as: biodiversity, ethnobotany, ethnocosmetology, traditional knowledge, ABS (access to genetic resources and Benefit Sharing), world heritage, phytochemistry, biological activities, bioassays, natural products valuation. Focus on "Cosmetopoeia concept" will launch discussions about renewing interests of "plants of the past" for "future valuations" namely as biosourcing ingredient for cosmeceuticals and will inspire innovative ways for sustainable development of different countries and cultures over the world.

Acknowledgements. We are grateful to Cosmetic-Valley for their financial support to this project.

Conflicts of interest. The authors declare that they have no conflicts of interest in relation to this article.

\section{References}

Ansel JL, Butaud JF, Nicolas M, Lecellier G, Pichon C, Raharivelomanana P. 2015. Le tamanu et ses propriétés en dermocosmétique. $L a$ Phytothérapie Européenne 86: 10-12.

Ansel JL, Lupo E, Mijouin L, et al. 2016. Biological activity of Polynesian Calophyllum inophyllum oil extract on human skin cells. Planta Medica 82(11-12): 961-966.

Bhalla TN, Saxena RC, Nigam SK, Misra G, Bhargava KP. 1980. Calophyllolide-a new non-steroidal and anti-inflammatory agent. Indian J Med Res 72: 762-765.

Bruneton J. 2009. Pharmacognosie, phytochimie, plantes médicinales, $4^{\mathrm{e}}$ ed. Paris : Éditions Tec \& Doc Lavoisier.

Conesa A, Götz S, García-Gómez JM, Terol J, Talón M, Robles M. 2005. Blast2GO: a universal tool for annotation, visualization and analysis in functional genomics research. Bioinformatics 21: 3674-3676.

Dweck AC, Meadows T. 2002. Tamanu (Calophyllum inophyllum)the African, Asian, Polynesian and Pacific Panacea. Int $J$ Cosmetic Sci 24 (6): 341-348.

Florence J. 2004. Flore de la Polynésie française, Collection Faune et Flore Tropicales 41, vol. 2. Paris: IRD Éditions, Publications scientifiques du Muséum.

Harrow J, Frankish A, Gonzalez JM, et al. 2012. GENCODE: the reference human genome annotation for The ENCODE Project. Genome Res 22: 1760-1774.

Hostettmann K. 2011. Tout savoir sur les vertus thérapeutiques, santé, beauté, longévité des fruits exotiques. Lausanne: Ed. Favre S.A.

Khilam C. 2004. Tamanu oil, a tropical remedy. American Herbal Gram 63: 26-31.

Krafts KP. 2010. Tissue repair: The hidden drama. Organogenesis 6: 225-233.

Laure F. 2005. Étude de la composition chimique et de la biodiversité du Calophyllum inophyllum de Polynésie française Thèse de doctorat, Université de la Polynésie française, Papeete, Tahiti, Polynésie Française.

Lederer E, Dietrich P, Polonsky J. 1953. On the chemical constitution of calophylloide and calophyllic acid from the nuts of Calophyllum inophyllum. Bull Soc Chim Fr 5: 546-549. 
Léguillier T, Lecsö-Bornet M, Lémus C, et al. 2015. The wound healing and antibacterial activity of five ethnomedical Calophyllum inophyllum oils: an alternative therapeutic strategy to treat infected wounds. PLoS One 10(9): e0138602. doi: 10.1371/ journal.pone.0138602.

Leu T. 2009. Contribution à la connaissance de la flore polynésienne: évaluation de l'intérêt pharmacologique de quelques plantes médicinales et étude phytochimique du Tamanu (Calophyllum inophyllum L.-Clusiaceae). Thèse de doctorat, Université de la Polynésie française, Papeete, Tahiti, Polynésie Française.

Leu T, Raharivelomanana P, Soulet S, Bianchini JP, Herbette G, Faure R. 2009. New tricyclic and tetracyclic pyranocoumarins with an unprecedented C-4 substituent. Structure elucidation of tamanolide, tamanolide D and tamanolide $\mathrm{P}$ from Calophyllum inophyllum of French Polynesia. Magn Reson Chem 47: 989-993.

Mariette-Chanson N. 2006. Study of Calophyllum inophyllum oil: clinical use demonstrates its healing properties (Étude sur l'huile de Calophyllum inophyllum: travaux cliniques démontrant les propriétés cicatrisantes de l'huile). Phytothérapie 4(4): 167-171.

Martin P. 1997. Wound healing: aiming for perfect skin regeneration. Science 276(5309): 75-81.

Nguyen V-L, Truong C-T, Nguyen BCQ, et al. 2017. Antiinflammatory and wound healing activities of calophyllolide isolated from Calophyllum inophyllum Linn. PloS One 12(10): e0185674. Available from https://doi.org/10.1371/journal. pone. 0185674 .

Pétard P. 1986. Plantes utiles de Polynésie et Raau, Haere Po No eds. Tahiti : Papeete, pp. 224-225.

Said T, Dutot M, Martin C, et al. 2007. Cytoprotective effect against UV-induced DNA damage and oxidative stress: role of new biological UV filter. Eur J Pharm Sci Off J Eur Fed Pharm Sci 30: 203-210.

Saravan R, Dhachinamoorthi D, Senthilkumar K, Thamizhvanan K. 2011. Antimicrobial activity of various extracts from various parts of Calophyllum inophyllum. J Appl Pharm Sci 1: $102-106$.

Sivamani RK, Garcia MS, Isseroff RR. 2007. Wound re-epithelialization: modulating keratinocyte migration in wound healing. Front Biosci 12: 2849-2868.

Stevens PF. 1980. A revision of the old species of the Calophyllum (Guttiferae). J Arnold Arbor Harv Univ 61: 117-424.

Whistler WA. 1992. Polynesian Herbal Medicine. Lawai, Kauai: National tropical botanical garden.

Yimdjo MC, Azebaze A, Nkengfack AE, Meyer AM, Bodo B, Fomum ZT. 2004. Antimicrobial and cytotoxic agents from Calophyllum inophyllum. Phytochemistry 65: 2789-2795.

Cite this article as: Raharivelomanana P, Ansel J-L, Lupo E, Mijouin L, Guillot S, Butaud J-F, Ho R, Lecellier G, Pichon C. 2018. Tamanu oil and skin active properties: from traditional to modern cosmetic uses. OCL 25(5): D504. 